\title{
Legal Status of Village Regulations in the Unitary State of the Republic of Indonesia
}

\author{
Dodi Jaya Wardana ${ }^{1}$ \\ Sukardi $^{2}$ \\ Radian Salman $^{3}$ \\ ${ }^{1}$ Faculty of Law, Universitas Muhammadiyah Gresik \\ dodijayawardana@umg.ac.id

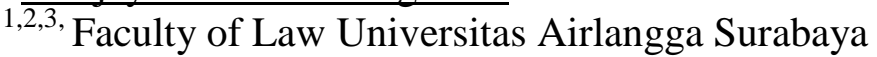

\begin{abstract}
ABSTRAK
Peraturan desa ditunjukan sebagai suatu perangkat dasar legitimasi penyelenggara pemerintah desa dalam menjalankan roda pemerintahan desa, dengan kata lain peraturan desa disusun sebagai acuan dalam melaksanakan pemerintahan dan pembangunan di desa. Tujuan penelitian ini adalah untuk mengetahui status hukum peraturan desa dalam perundang-undangan Indonesia. Selain itu untuk mengetahui demokratisasi dalam menjalankan pemerintahan desa. Metode penelitian yang digunakan adalah metode penelitian hukum normative yang mengkaji undang-undang dan literature terkait. Hasil penelitian menunjukkan bahwa status hukum peraturan desa dalam sistem peraturan perundang-undangan masih tetap diakui dan kedudukan Peraturan Desa sebagai produk hukum Desa telah memiliki pijakan yuridis yang sangat kuat dengan lahirnya Undang-Undang Nomor 6 Tahun 2014 Tentang Desa. Meskipun Peraturan Desa sudah tidak lagi muncul di dalam hierarki Peraturan perundang-undangan setelah lahirnya atau berlakunya Undang-Undang Nomor 12 Tahun 2011 Tentang Pembentukan Peraturan perundang-Undangan, namun keberadaannya diatur secara tegas dan kedudukan Peraturan Desa semakin kuat karena telah dijadikan sandaran yuridis pengaturan Desa dengan terbitnya Undang-Undang Nomor 6 Tahun 2014 Tentang Desa. Dihapusnya Peraturan Desa dari hierarki Peraturan perundang-undangan tidak menimbulkan implikasi atau dampak terhadap penyelenggaraan pemerintahan Desa, karena badan permusyawaratan Desa tetap dapat membentuk Peraturan Desa bersama dengan kepala Desa atas dasar yang kuat yaitu Undang-Undang Nomor 6 Tahun 2014 Tentang Desa.
\end{abstract}

Kata Kunci: Status Hukum, Peraturan Desa, Indonesia

\begin{abstract}
Village regulations are shown as a basic device for the legitimacy of village government administrators in running the village government, in other words, village regulations are prepared as a reference in implementing government and development in the village. The purpose of this study was to determine the legal status of village regulations in Indonesian legislation. In addition to knowing democratization in running village government. The research method used is a normative legal research method that examines laws and related literature. The results of the study indicate that that the legal status of village regulations in the statutory system is still recognized and the position of Village Regulations as a village legal product has a very strong juridical footing with the enactment of Law Number 6 of 2014 concerning Villages. Although Village Regulations no longer appear in the hierarchy of laws and regulations after the birth or enactment of Law Number 12 of 2011 concerning the Establishment of Legislations, their existence is strictly regulated and the position of Village Regulations is getting stronger because they have been used as a juridical basis for village regulations. With the issuance of Law Number 6 of 2014 concerning Villages.
\end{abstract}

Key words: Legal Status Village Regulations; Indonesia. 


\section{INTRODUCTION}

Village regulations are shown as a basic device for the legitimacy of village government administrators in running the village government, in other words, village regulations are prepared as a reference in implementing government and development in the village. Village by Law number 32 of 2004 said village is a unit of community boundaries of territorial jurisdiction, authority to regulate and manage the interests of local communities based on the origin and the local customs are recognized and / or established in the government system national and located in the district/city. The rationale for village regulation is diversity, participation, genuine autonomy, democracy and community empowerment.

The autonomy possessed by the village or other designations and to the village through the village government can be assigned or delegated from the government or local government to carry out certain government affairs. As an embodiment of democracy, in the implementation of village governance, a Village Consultative Body or other designations are formed in accordance with the developing culture in the village concerned, which functions as a regulatory agency in the administration of village government, such as in the making and implementation of village regulations, village income and expenditure budgets, and village chief's decision.

In Article 209 of Law Number 32 of 2004 it is explained that the Village Consultative Body has the function of establishing Village Regulations with the Village Head, accommodating and channeling community aspirations. Then in Article 212 paragraph (5) it is stated that the village financial management as referred to in paragraph (2) is carried out by the village head as outlined in the village regulation concerning the village income and expenditure budget. The existence of regulations related to the village regulations above shows that the village is an autonomous government or region that can run its own government.

The preparation of village regulations is an elaboration of the various authorities owned by the village, such as the existing authority based on the rights of village origin, the authority obtained through the laws and regulations on it as village affairs, further elaboration of statutory regulations and other government affairs that by legislation is submitted to the village, which of course in its preparation must not conflict with the public interest and higher laws and regulations.

Furthermore, Law Number 6 of 2014 concerning Villages. Village regulations are stipulated by the Village Head after being discussed and agreed upon with the Village Consultative Body which is a legal and policy framework for implementing Village Government and Village Development. The stipulation of Village Regulations is an elaboration of the various authorities possessed by the Village referring to the provisions of higher laws and regulations. As a legal product, Village Regulations must not conflict with higher regulations and must not harm the public interest

Along the way, the regulations regarding the existence of village regulations have changed. Initially village regulations were accommodated explicitly in the hierarchy of statutory regulations, namely in Article 1 point 8 of Law Number 10 of 2004 concerning the formation of laws and regulations it was stated that: Village Representative Body or other names together with the Village Head or other names. And Article 7 paragraph (1) types and hierarchy of laws and regulations are as follows: a. the 1945 Constitution of the Republic of Indonesia; b. Laws/Government Regulations in Lieu of Laws; c. Government regulations; d. Presidential decree; e. Local regulation. In paragraph (2) it is emphasized that the Regional Regulation as referred to in paragraph (1) letter e includes: a. Provincial Regulations are made by the Provincial Regional People's Representative Council 
together with the Governor; b. Regency/City Regional Regulations are made by the Regency/City Regional People's Representative Council together with the Regent/Mayor; c. Village

Regulations/ level regulations, made by the Village Representative Body or other names together with the Village Head or other names. And paragraph (3) states, further provisions regarding procedures for the conduct of village regulations/regulations at the same level are regulated by the relevant district/city regulations.

Starting from the description above, it can be said that in Law Number 10 of 2004, Village Regulations are set as one type of Legislation in Indonesia. However, with the enactment of Law Number 12 of 2011 concerning the Establishment of Legislation as a substitute for Law Number 10 of 2004, the position of Village Regulations became unclear, not even regulated and not included in the hierarchical system of Legislation. In Indonesia. The Village Head Regulation which is the implementing rule of the Village Regulation, and is positioned under the Village Regulation is more regulated and incorporated into the Legislation system in Indonesia.

Furthermore, in Law Number 12 of 2011, the regulation regarding the hierarchy or position/position of Village Regulations unregulated. If we look carefully at Law Number 12 of 2011, we do not find the position of Village Regulations as an explicit type and position in the hierarchy of laws and regulations. It can be explicitly traced in Article 7 paragraph (1) of Law Number 12 of 2011, in that article the types and hierarchies of laws and regulations are described as follows: the 1945 Constitution of the Republic of Indonesia, Decree of the People's Consultative Assembly, Law Government Laws/Regulations in Lieu of Laws, Government Regulations, Presidential Regulations, Provincial Regulations, and Regency/Municipal Regulations. Although Article 7 paragraph (1) of Law Number 12 of
2011 has clearly stated the types and hierarchies of statutory regulations, in Article 8 paragraph (1) of Law Number 12 of 2011 still expands the scope of legislation.

The scope of the types of legislation expanded in this article is stated in detail as follows: Types of legislation other than those referred to in Article 7 paragraph (1) include regulations stipulated by the People's Consultative Assembly, the People's Representative Council, the Regional Representatives Council, the Court Supreme Court, Constitutional Court, Supreme Audit Agency, Judicial Commission, Bank Indonesia, Minister, Agency, Institution, or Commission of the same level established by law or by the Government on the orders of the Act, Provincial House of Representatives, Governor, House of Representatives Regency/City area, Regent/Mayor, Village Head or equivalent.

From these provisions, the problem that arises is where is the position of Village Regulations as a type and hierarchy in the laws and regulations in Indonesia with the enactment of Law Number 12 of 2011 concerning the Establishment of Legislative Laws. The formulation of the problem in research in is Democratization in Village Governance and Legal Status of the Village Regulations in Indonesian Legislation.

\section{RESULTS}

Democracy in village government is related to a democratic village policy or regulation if it is community-based originating from community participation, managed responsibly and transparently by the community and used to provide benefits to the community.

Furthermore, in terms of the context of community-based (democratic) Village Regulations, each Village Regulation must be relevant to the context of community needs and aspirations. In other words, the Village Regulations made are intended to answer the needs of the community, not just to formulate 
the wishes of the village elite or just to carry out instructions from the supra-village government. In terms of context (substance), the basic principle is that Village Regulations are more restrictive in nature and at the same time protect the weak. At the very least, the Village Regulations must provide firmness regarding the accountability of the Village government and the Village Consultative Body in managing village governance (Ni'matul Huda, 2012).

Viewed from the benefits for the people, Village Regulations are intended to encourage community empowerment, provide space for the development of community creations, potentials and innovations for public goods, and provide space for community participation in the government process and village development. Community participation can be seen from the consultation on the draft Village Regulation to the community. As stated in Article 69 paragraphs (9) and (10) of Law Number 6 of 2014 concerning Villages, namely: Paragraph (9) The Draft Village Regulation must be consulted with the Village community and Paragraph (10) Village Community has the right to provide input on the Draft Regulation Village. Meanwhile, to create order and balance, Village Regulations must be restrictive: prevent exploitation of natural resources and community members, prohibit environmental destruction, prevent criminal acts, and prevent domination of one group over another, and so on.

In accordance with the logic and ethics of democracy, community-based (democratic) Village Regulations are prepared through a democratic public policy cycle process: Articulation, Aggregation, Formulation, Public Consultation, Revision or Formulation, Legislation, Socialization, Implementation, and Control and Evaluation. In each of these sequences, the community has the space (access) to be actively involved in conveying their voice. Articulation is the process of absorption of community aspirations performed by Village Consultative Body and village officials. Aggregation is the process of collecting, reviewing and prioritizing aspirations which will be formulated into Village Regulations. Formulation is the process of formulating a draft Village Regulation which can be carried out by the Village Consultative Body or by the Village government. Consultation is a process of joint dialogue between the Village government and the Village Consultative Body with the community. The community has space to observe, criticize, provide input and revise the draft Village Regulation. The Village Government and the Village Consultative Body are required to revise the draft Village Regulation based on feedback from the community in the previous consultation process.

The revised draft Village Regulation is then ratified (legislation) into a Village Regulation by the Village government and the Village Consultative Body. Before the Village Regulation is implemented, the Village government and the Village Consultative Body are required to conduct public outreach, to provide information about the Village Regulation so that the community knows and is ready to implement or support the Village Regulation.

The stipulation of Village Regulations is an elaboration of various powers owned by the Village referring to the provisions of higher laws and regulations. As a legal product, Village Regulations must not conflict with higher regulations and must not harm the public interest, namely: a. Disruption of harmony between members of the community; b. Disruption of access to public services; c. disturbance of peace and public order; d. Disruption of economic activities to improve the welfare of the Village community; and e. Discrimination against ethnicity, religion and belief, race, intergroup, and gender.

As a political product, Village Regulations are processed in a democratic and participatory manner, ie the drafting process includes the 
participation of the Village community. The Village Community has the right to propose or provide input to the Village Head and the Village Consultative Body in the process of drafting Village Regulations. Village regulations that regulate Village authority based on origin rights and local-scale authority of the Village, its implementation is supervised by the Village community and the Village Consultative Body. It is intended that the implementation of Village Regulations can always be monitored on an ongoing basis by local Village community members considering that Village Regulations are stipulated for the benefit of the Village community.

If there is a violation of the implementation of the Village Regulation that has been determined, the Village Consultative Body is obliged to remind and follow up on the violation in accordance with the authority it has. That is one of the supervisory functions of the Village Consultative Body. In addition to the Village Consultative Body, the Village community also has the right to conduct participatory monitoring and evaluation of the implementation of Village Regulations.

The types of regulations that exist in the Village, in addition to the Village Regulations are the Village Head Regulations and the Village Head Joint Regulations. The joint regulation of the Village Head is a regulation set by the Village Head of 2 (two) or more Villages conducting inter-Village cooperation. The joint regulation of the Village Head as referred to in paragraph (1) is a combination of the interests of each Village in inter-Village cooperation.

Law No. 12 of 2011 on the establishment of Regulatory has given recognition to village rules as legislation in Indonesia. What is meant by a village regulation according to Law Number 12 of 2011 concerning the Establishment of Legislative Regulations is a statutory regulation made by the Village Representative Body or under another name together with the Village Head or other names. The procedure for the preparation of Act up to local regulation/ cities regulated in Law Number 12 of 2011, whereas the provisions concerning the procedure of making village regulations delegated by Act No. 12 of 2011 to be regulated by the Rules of the Regency / the city in question. The delegation that regulates the procedures for making this Village Regulation is apparently intended to accommodate the diversity of villages in each district or city.

Prior to the enactment of Law Number 12 of 2011 concerning the Establishment of Legislations, Village Regulations were part of Regional Regulations which included the types of laws and regulations regulated in Article 7 paragraph (2) letter c of Law Number 10 of 2004 concerning the Establishment of Regulations Legislation. After the enactment of Law no. 12 of 2011 concerning the Establishment of Legislations, Village Regulations are not explicitly mentioned as one of the laws and regulations. However, the position of Village Regulations is actually still a statutory regulation. This is based on the provisions of Article 8 paragraph 1 of Law Number 12 of 2011:

"Types of Legislation other than those referred to in Article 7 paragraph (1) include Regulations stipulated by the People's Consultative Assembly, the People's Representative Council, the Regional Representatives Council, the Supreme Court, the Constitutional Court, the Supreme Audit Agency, the Judicial Commission, Bank Indonesia, the Minister, agency, institution or commission of the same level established by law or by the Government on the orders of the Act, the Provincial People's Representative Council, the Governor, the Regency/City Regional People's Representative Council, the Regent/Mayor, the Village Head or the equivalent."

The recognition of the existence of a Village Regulation and having binding legal force as long as it is ordered by a higher 
regulation or formed based on (formal) authority, is emphasized in Article 8 paragraph (2) of Law Number 12 of 2011. Based on Article 101 of Law Number 12 In 2011, all laws and regulations which are implementing regulations of Law Number 10 of 2004, are declared still valid as long as they do not conflict with the provisions of Law Number 12 of 2011. Although the Village government cannot simply form a Village Regulation to describe a higher level statutory regulation if there is no order from the legislation or delegation because the original affairs or authority held by the Village are very limited.

The legal status of the existence of Village Regulations in or is also in Law Number 6 of 2014 concerning Villages, in Article 69 it is determined that the Types of Regulations in the Village consist of Village Regulations, Joint Regulations of the Village Head, and Village Head Regulations. Regulations in the Village are prohibited from conflicting with the public interest and/or the provisions of higher laws and regulations. Village regulations are stipulated by the Village Head after being discussed and agreed with the Village Consultative Body. Draft Village Regulations concerning Village Revenue and Expenditure Budgets, levies, spatial planning, and Village Government organizations must obtain an evaluation from the Regent/Mayor before being stipulated as a Village Regulation. The results of the evaluation are submitted by the Regent/Mayor no later than 20 (twenty) working days from the receipt of the draft Regulation by the Regent/Mayor. In the event that the Regent/Mayor has provided the results of the evaluation, the Village Head must correct it. The Village Head is given a maximum of 20 (twenty) days from the receipt of the evaluation results to make corrections. In the event that the Regent/Mayor does not provide evaluation results within the time limit, the Village Regulation shall apply automatically. The Draft Village Regulation must be consulted with the Village community. The Village Community has the right to provide input on the Draft
Village Regulation. Village Regulations and Village Head Regulations are promulgated in the Village Gazette and Village News by the Village secretary. In implementing the Village Regulation, the Village Head stipulates the Village Head Regulation as the implementing rule. In Article 70 it is determined that the joint regulation of the village head is a regulation determined by the village head of 2 (two) or more villages that collaborate between villages. The joint regulation of the Village Head as referred to in paragraph (1) is a combination of the interests of each Village in inter-Village cooperation.

Furthermore, Village Regulations are local regulations. Village regulations are formed based on the principles of statutory regulations. A. Hamid S. (2009:24) states that the principles for the formation of legislation that should be specifically in the Indonesian realm, consist of: the ideals of Indonesian law, the principles of the state based on law, the principles of governance based on the constitution and other principles. In the formation of laws and regulations, in addition to adhering to the principles of the formation of good legislation, it is also based on general legal principles, which consist of general state law principles based on law, general government legal principles based on the constitutional system, legal principles state based on people's sovereignty (Maria Farida, 1998:196-197).

Furthermore, Law Number 6 of 2014 concerning Villages. Village regulations are stipulated by the Village Head after being discussed and agreed upon with the Village Consultative Body which is a legal and policy framework for implementing Village Government and Village Development. The stipulation of Village Regulations is an elaboration of the various authorities possessed by the Village referring to the provisions of higher laws and regulations. As a legal product, Village Regulations must not conflict with higher regulations and not harm the public interest. 
As a political product, Village Regulations are processed in a democratic and participatory manner, i.e. the drafting process includes the participation of the Village community. The Village Community has the right to propose or provide input to the Village Head and the Village Consultative Body in the process of drafting Village Regulations. The types of regulations that exist in the village, in addition to village regulations, are village head regulations and village head joint regulations. Village regulations are prohibited from conflicting with the public interest and/or the provisions of higher laws and regulations.

In Law Number 6 of 2014 concerning Villages, it is found that it is considered more lax in decentralizing power over the Village. The law revives the role of the Village Consultative Body as the Village parliament to supervise Village policies, especially in forming Village Regulations. When viewed from the hierarchical structure of all types of statutory regulations in Indonesia, then this is not only determined solely, but it is more because the statutory regulations in Indonesia are not only formed by different institutions, but also each have different functions and content at the same time according to the level, so that the hierarchy, function and content of laws and regulations always form a functional relationship between one legislation and another (Maria Farida, 2010:235 ) .

The Village Regulation is a form of legal product produced by the government at the Village level made by the Village Consultative Body together with the Village head where the procedure for its formation is regulated by the relevant Regency/City Regional Regulation. Village regulations are usually local in nature and usually relate to Village Customs/communities and bind the local community or other Village residents temporarily living in the village. Village regulations are also a further elaboration of higher regulations by taking into account the conditions and culture of the local community. Although Village Regulations no longer appear in the hierarchy of laws and regulations after the birth or enactment of Law Number 12 of 2011 concerning the Establishment of Legislations, their existence is strictly regulated and the position of Village Regulations is getting stronger because they have been used as a juridical basis for village regulations. With the issuance of Law Number 6 of 2014 concerning Villages.

Law Number 12 of 2011 concerning the Establishment of Legislations still recognizes the existence of Village Regulations as stipulated in Article 8 paragraph (2), which states that the laws and regulations as referred to in paragraph (1) are recognized for their existence and have binding legal force. As long as it is ordered by a higher statutory regulation or is formed based on authority. In the context of Law Number 12 of 2011 concerning the Establishment of Legislations, the hierarchy of laws and regulations is no longer solely based on a structural hierarchy, but also a functional hierarchy, so that functionally Village Regulations are not legal products that are prohibited, but are still recognized existence and have legal binding power. The removal of Village Regulations from the hierarchy of statutory regulations does not have any implications or impacts on the administration of Village governance, because the Village Consultative Body can still form Village Regulations together with the Village head on a strong basis, namely Law Number 6 of 2014 concerning Villages.

\section{CONCLUSION}

Based on the description above, it can be concluded that the legal status of village regulations in the statutory system is still recognized and the position of Village Regulations as Village law products has a very strong juridical footing with the birth of Law Number 6 of 2014 concerning Village. Although Village Regulations no longer appear in the hierarchy of laws and 
regulations after the birth or enactment of Law Number 12 of 2011 concerning the Establishment of Legislations, their existence is strictly regulated and the position of Village Regulations is getting stronger because they have been used as a juridical basis for village regulations. With the issuance of Law Number 6 of 2014 concerning Villages. Law Number 12 of 2011 concerning the Establishment of Legislations still recognizes the existence of Village Regulations as specified in Article 8 paragraph (2), which states that the laws and regulations as referred to in paragraph (1) are recognized for their existence and have binding legal force. As long as it is ordered by a higher statutory regulation or is formed based on authority. In the context of Law Number 12 of 2011 concerning the Establishment of Legislations, the hierarchy of laws and regulations is no longer solely based on structural hierarchies, but is also adopted by functional hierarchies, so that functionally Village Regulations are not legal products that are prohibited, but are still recognized. Existence and have legal binding power. The removal of Village Regulations from the hierarchy of statutory regulations does not have any implications or impacts on the administration of Village governance, because the Village Consultative Body can still form Village Regulations together with the Village head on a strong basis, namely Law Number 6 of 2014 concerning Villages.

\section{REFERENCES}

Arifin, Syamsul. (2012). Hukum Perlindungan dan Pengelolaan Lingkungan Hidup di Indonesia. Jakarta: Sofmedia.

Efendi, Lutfi. (2003). Pokok-Poko Hukum Administrasi Negara. Malang: Bayumedia Publishing.

Fauzi, Nur dan R. Yando Zakaria. (2000). Mensiasati Otonomi Daerah. Yogyakarta: Konsorsium Pembaharuan Agraria bekerjasama dengan INSIST "Press".
Ganjong, Agus Salim Andi. (2007). Pemerintahan Daerah Kajia Politik dan Hukum. Bogor: Ghalia Indonesia.

Hajdon, Philipus M. 2008. Pengantar Hukum Administrasi Indonesia, cet. 10. Yogyakarta: Gadjah Mada University Press.

Hadjon, Philipus M. dkk. (2010). Hukum Administrasi dan Good Governance. Jakarta: Penerbit Universitas Trisakti.

Hendratno, Edie Toet. (2009). Negara Kesatuan, Desentralisasi, dan Federalisme. Jakarta: Graha Ilmu dan Universitas Pancasila Press.

Kartasapoetra, RG. 1987. Sistematika Hukum Tata Negara. Jakarta: Bina Aksara.

Koeswara, E. (2001). Otonomi Daerah, Untuk Demokrasi dan Kemandirian Rakyat. Jakarta: Yayasan PARIBA.

Marzuki, Peter Mahmud. (2010). Penelitian Hukum, Cet. 6. Jakarta: Kencana Prenada Media Group.

Soehino. (2006). Hukum Tata Negara Teknik Perundang-Undangan. Yogyakarta: Anggota IKAPI.

Sukriono, Didik. (2010). Pembaharuan Hukum Pemerintahan Desa, Politik Hukum Pemerintahan Desa Di Indonesia. Malang: Setara Fress (Kelompok InTRANS Publishing.

Wasistiono, Sadu dan M. Irwan Tahir. (2007). Prospek Pengembangan Desa. Bandung: CV. FOKUS MEDIA-Anggota IKAPI.

Widjaja, HAW. (2003). Pemerintahan Desa/Marga Berdasarkan UndangUndang Nomor 22 Tahun 1999 Tentang Pemerintahan Daerah. Jakarta: PT Raja Grapindo Persada.

Widjaja, HAW (2004). Otonomi Desa Merupakan Otonomi Yang Asli Bulat Dan Utuh. Jakarta: PT Raja Grapindo Persada. 